\title{
SEASONAL OCCURRENCE AND ABUNDANCE OF WATERBIRDS IN SANDPITS AND FISHPONDS
}

\author{
MARIE KAMENÍKOVÁ and JOSEF RAJCHARD*
}

University of South Bohemia in České Budějovice, Faculty of Agriculture, Department of Biology, Studentská 13,
37005 České Budějovice, Czech Republic
${ }^{*}$ Corresponding author: rajchard@zf.jcu.cz

\section{ABSTRACT}

Censuses of waterfowl at four fishponds and sandpits in the surroundings of Treboň were carried out regularly during one season and their occurrence was compared with that recorded by other studies and information in the database of the Treboňsko Protected Landscape Area. Some waterfowl show a marked preference for fishponds during the breeding season. This can be due to many factors, presence of more food, extent of the littoral growth of vegetation, fish stock, depth of water etc. However, sandpits are attractive to waterbirds in winter, when they serve as over wintering sites, meeting places for migrating birds or refuges from hunters.

Keywords: waterbirds, fishponds, sandpits, comparison, occurrence

\section{Introduction}

Třeboň Basin is an area, which was reconfigured by humans several hundred years ago by converting most of the natural wetland there into fishponds that are up to several hundred hectares in area and interconnected with each other by a system of drainage streams. The whole region is a Protected Landscape Area (PLA), Biosphere Reserve (BR) and Important Bird Area (IBA), primarily because of the occurrence and nesting there of many species of water and wetland birds.

Currently there are nearly 500 fishponds in the Třeboň Basin covering a total area of over 7200 hectares. The primary function of fishponds is fish farming (mostly common carp - Cyprinus carpio) but by their gradual integration into the surrounding landscape, they became suitable habitats for many water animals, water plants and wetland species.

Their shallow depth (up to $1 \mathrm{~m}$ ) and water rich in nutrients resulted in the development of an extensive littoral vegetation. These shallow reservoirs partly overgrown with aquatic vegetation are suitable habitats for some species of waterbirds (Bezzel 1976; Lutz 2011). Due to intensive fish farming, fishpond trophy and increase in fish stock density the littoral vegetation was restricted (Musil 2000). In the late 70s and early 80s of the 20th century the abundance of waterbirds changed, with some species declining in abundance. The reasons were mainly due to hydrological changes, agricultural intensification, changes in the industrial and urban landscape, human activities and natural vegetation (Hudec et al. 2000).

A relatively new and qualitatively different explanation for the high occurrence of waterbirds in this area are sandpits (Matter and Manna 1998). Unlike fishponds, sandpits are at most 50 years old. The water in sandpits is oligo- or mesotrophic. Unlike fishponds, sandpits are as deep as $22 \mathrm{~m}$ and littoral vegetation only sporadically colonizes the steep sides of the sand pits. Recently, some of these sandpits have been used as reservoirs for water supply and some for recreational purposes, including fishing. Barragan-Severo et al. (2002) report that these artificial water reservoirs are important habitats for waterbirds, as they are close to migration routes and used as stepping stones.

Each species chooses reservoirs (fishponds, sandpits) based on the conditions that prevail there (trophy, vegetation type etc.). Some waterbirds use sandpits, when other suitable habitats are lacking (Reitan and Sandvik 1996). Siddle and Kirsch (1993) report the nesting of endangered least tern (Sterna antillarum) and piping plover (Charadrius melodus) in sandpits in Nebraska, USA. Both of these endangered species found alternate nesting sites around lakes created by sand mining after their natural nesting sites in the river alluvium were mostly destroyed. Nowadays, about $60-90 \%$ of the current population of these species nest in sandpits. Hanák et al. (1985) study of the avifauna in sandpits in the Třebon area reveals that there are 25 species of bird in the Vlkov sandpit (of these 13 are waterbirds) and 40 in the Cep sandpit (of these 16 are waterbirds).

\section{Material and methods}

\section{Site characteristics}

For avifauna monitoring the Naděje fishpond system (NFS) was chosen (see Balounová et al. 1996 for details). It consists of 15 fishponds of from 1.66 to 63.50 ha in extent, which are used for intensive fish production, mostly carp (Cyprinus carpio). There is a zone of littoral vegetation around most fishponds consisting of mainly Phragmites australis, Typha angustifolia and Typha latifolia. One of these fishponds is a nature reserve and the management of the fishery there is less intense. 
Monitored sandpits were 13 reservoirs of similar area ranging from 9-123 hectares located at: Veselí - 5 reservoirs, $3 \mathrm{~km}$ north of the Naděje fishpond system (NFS), where mining has ceased, Cep $20 \mathrm{~km}$ south of NFS with 4 reservoirs (two of them still being mined) and Halám$\mathrm{ky}, 35 \mathrm{~km}$ south of NFS, with 4 reservoirs (one of them still being used for extracting sand).

\section{Methods of observation}

The populations of waterbirds at four sites in the Třebon area (an area comparable to the observed fishponds and sandpits) were counted at regular fixed intervals throughout the year. The Naděje fishpond system and Veselí sandpits were monitored throughout the year at two-week intervals, Cep sandpits and Halámky sandpits at four-week intervals. Monitoring of waterbirds at localities was done by counting the birds on the water and by searching for nests in comparable areas of littoral vegetation at these particular fishponds and sandpits (Janda and ̌̌epa 1986).

The monitoring of population abundance involved counting all the birds on the water and other species of birds associated with aquatic and wetland environments - birds of the orders Podicipediformes, Anseriformes, Pelecaniformes, Ciconiiformes, Charadriiformes, Gruiformes, Falconiformes, Coraciiformes and Passeriformes. For monitoring the birds BRESSER $10 \times 50$ binoculars and an eyepiece BRESSER 20-60 telescope were used.

\section{Statistical analysis}

The data, i.e. the sums of all individuals of each species observed during summer (April to September) and win- ter (October to March), were analyzed using ordination methods. The aim of lumping the data for each season was to increase the explanatory power of the analysis, because the occurrence of birds differed markedly between summer and winter, but the abundances recorded at each observation were usually relatively low and would therefore not meet the prerequisites for the use of multivariate methods.

In the direct gradient analysis CCA in the program CANOCO for Windows 4.5 the following environmental variables were used: type of watery locality, total depth of the reservoirs monitored, acreage of littoral vegetation at the localities monitored, diversity index, number of species of birds at the different localities and size of the fish stock. In the graph, the environmental variables selected were those that were not significant at the $5 \%$ significance level based on the MONTE CARLO permutation test. The resultant number of birds was logarithmically transformed (Statistica 2007).

\section{Results}

\section{List of species occurring at the localities monitored}

The following species of waterbirds occurred at the fishponds and sandpits from March 2005 to February 2006: little grebe (Tachybaptus ruficollis), great crested grebe (Podiceps cristatus), cormorant (Phalacrocorax carbo), little bittern (Ixobrychus minutus), night heron ( $N y c$ ticorax nycticorax), little egret (Egretta garzetta), great white egret (Egretta alba), grey heron (Ardea cinerea), mute swan (Cygnus olor), greylag geese (Anser anser), mallard (Anas platyrhynchos), gadwall (Anas strepera),

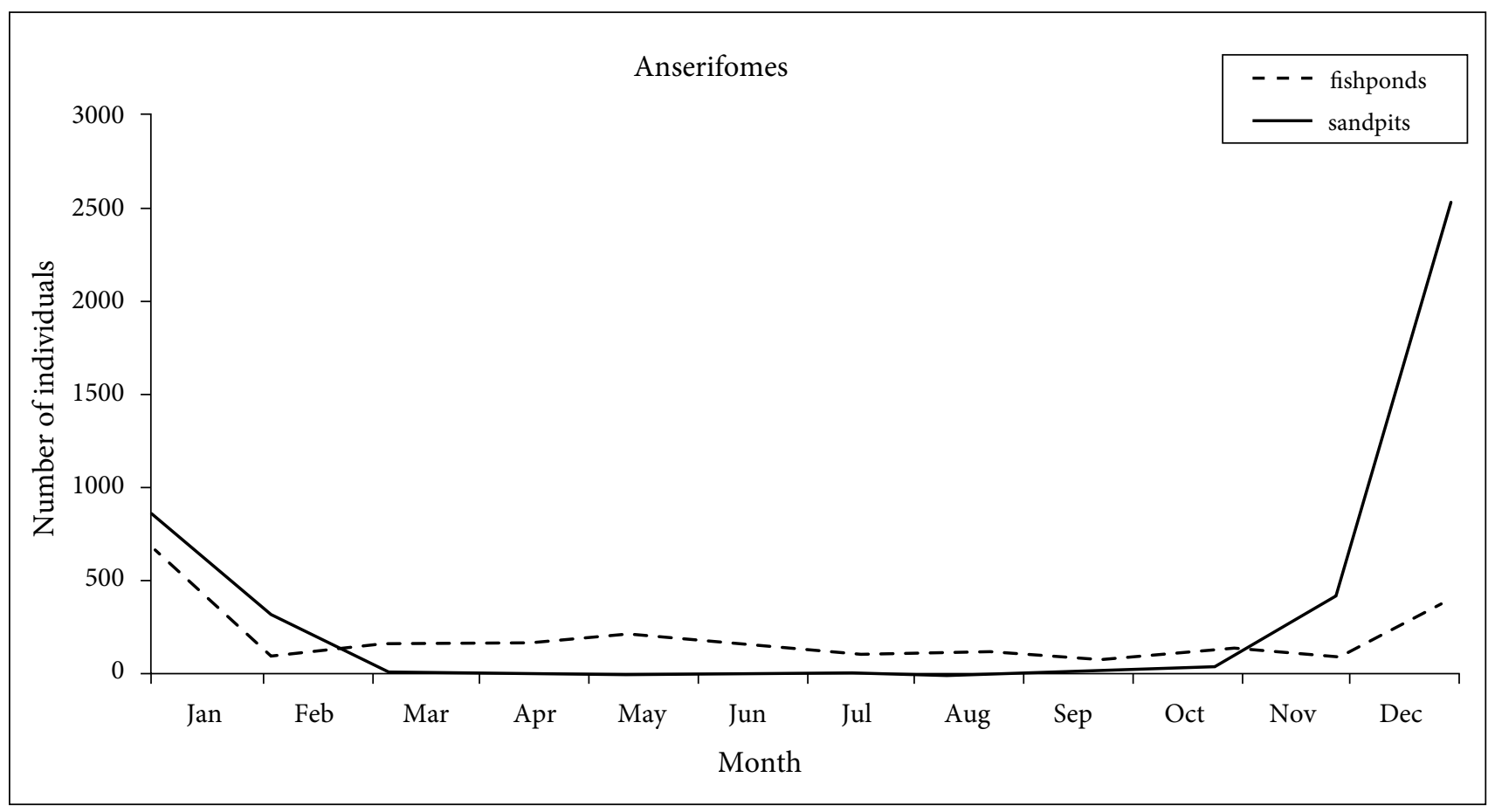

Fig. 1 Comparison of the abundance of birds of the order Anseriformes at NFS and sandpits in the Třeboň area. 


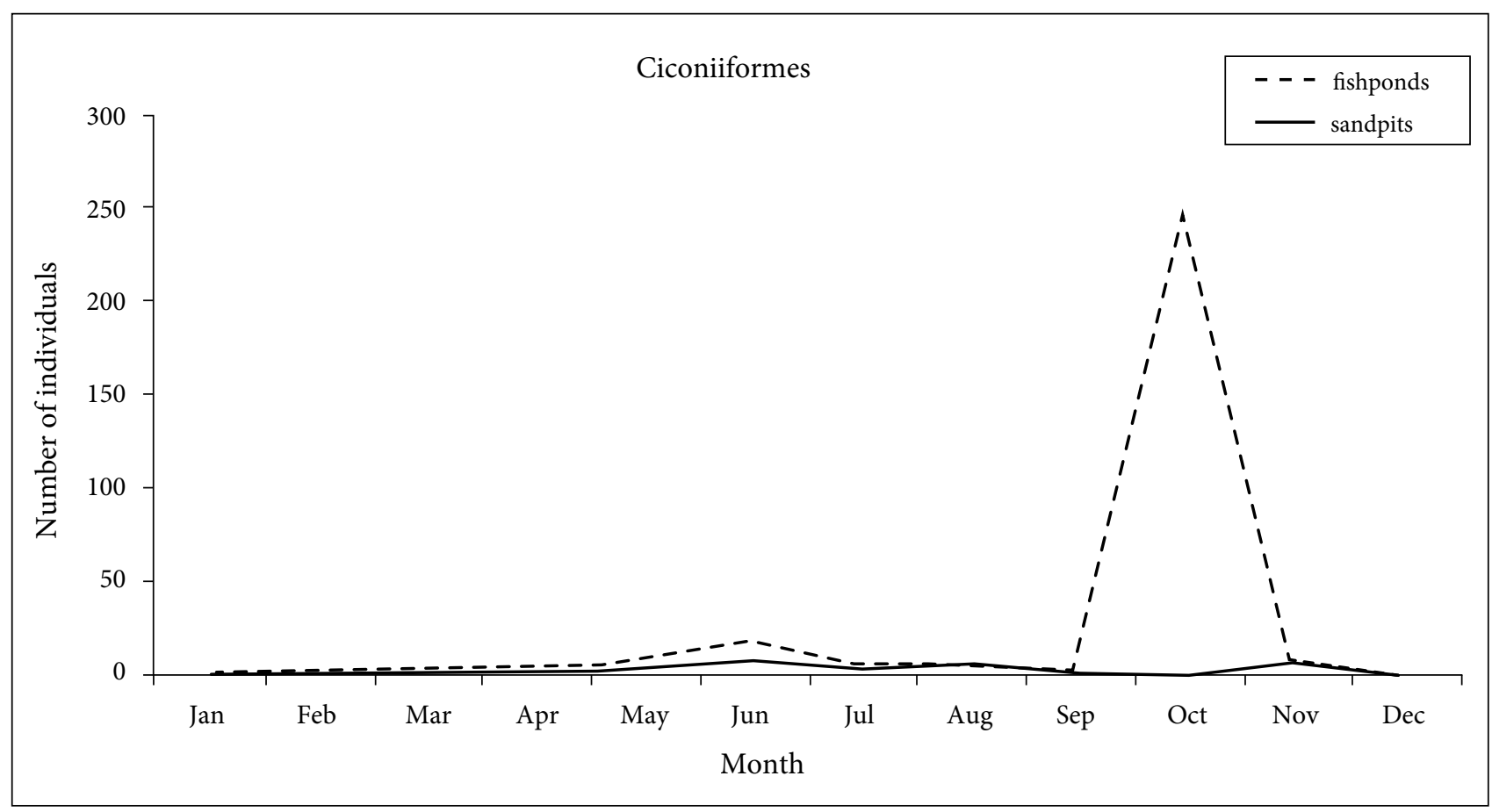

Fig. 2 Comparison of the abundance of birds of the order Ciconiiformes at NFS and sandpits in the Treboň area.

pochard (Aythya ferina), tufted duck (Aythya fuligula), goldeneye (Bucephala clangula), red-crested pochard (Netta rufina), osprey (Pandion haliaetus), white-tailed eagle (Haliaetus albicilla), marsh harrier (Circus aeruginosus), moorhen (Gallinula chloropus), coot (Fulica atra), black-headed gull (Larus ridibundus), common gull (Larus canus), common tern (Sterna hirundo), kingfisher (Alcedo atthis) and sand martin (Riparia riparia).

\section{Comparison of the abundance of waterbirds recorded at fishponds and sandpits}

In NFS, the most frequent species were black-headed gull (Larus ridibundus), mallard (Anas platyrhynchos) and great crested grebe (Podiceps cristatus). Compared to the NFS, there were no markedly frequent species recorded at the Veselí sandpits: these watery areas are not very attractive for waterbirds. Also in comparison with

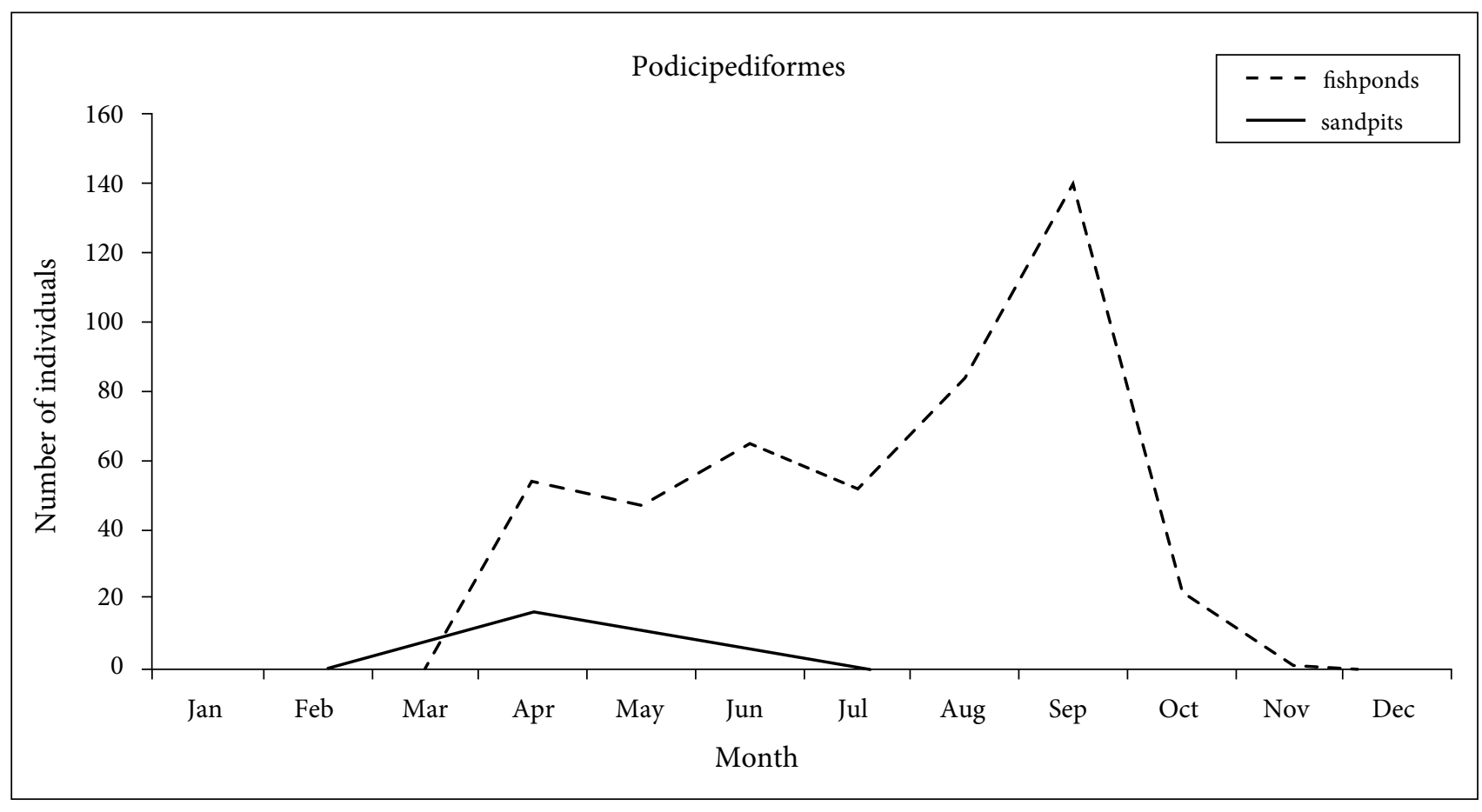

Fig. 3 Comparison of the abundance of birds of the order Podicipediformes at NFS and sandpits in the Třeboň area. 
other sandpits, the Veselí sandpits are less attractive for birds. During autumn and winter, mallard (Anas platyrhynchos) and cormorant (Phalacrocorax carbo) occurred abundantly, but less frequently than at other localities.

Although at the Veselí and Cep sandpit systems waterbirds were less abundant during the nesting season, in winter the Cep sandpit system was the locality with the greatest number of wintering waterbirds, mainly mallard (Anas platyrhynchos). A similar trend was also recorded for the Halámky sandpit system. Waterbirds were always significantly more numerous at fishponds than nearby sandpits (Figs 1, 2, 3).

A high incidence of the following bird orders was reported in the NFS: Anseriformes - mallard (Anas platyrhynchos), Gadwall (Anas strepera), pochard (Ay- thya ferina), tufted duck (Aythya fuligula), red-crested pochard (Netta rufina), goldeneye (Bucephala clangula), mute swan (Cygnus olor) and greylag geese (Anser anser), followed by Podicipediformes - great crested grebe (Podiceps cristatus), little grebe (Tachybaptus ruficollis) and Charadriiformes - black-headed gull (Larus ridibundus) and common tern (Sterna hirundo). Grey heron (Ardea cinerea), great white egret (Egretta alba), little egret (Egretta garzetta) and night heron (Nycticorax nycticorax) of the order Ciconiiformes were also relatively abundant at the fishpond localities, but less so than the species listed above. Abundance of birds of this order was not significantly different from their numbers recorded at sandpits, where only the grey heron (Ardea cinerea) was recorded. Bird abundance recorded in October, which

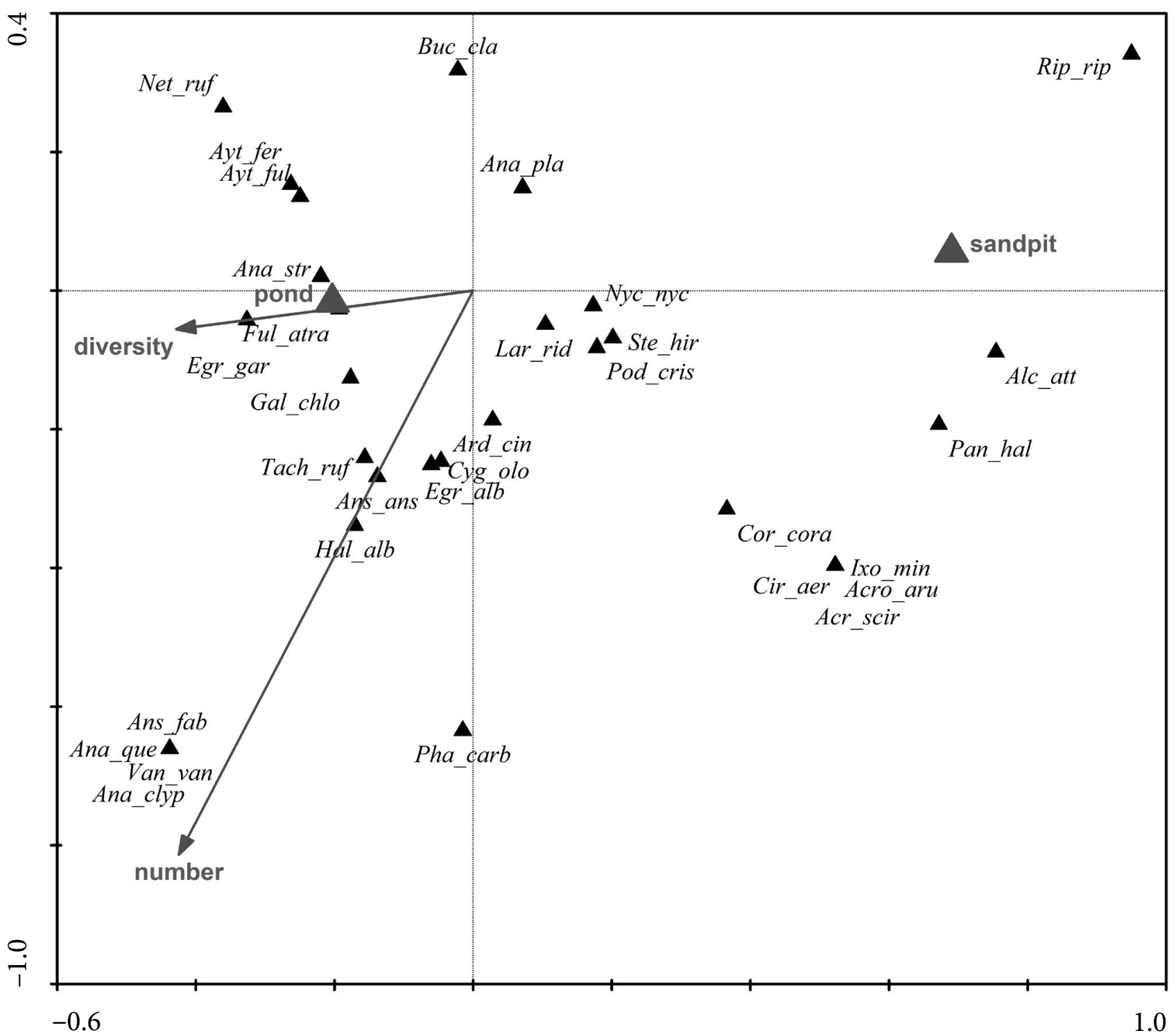

Fig. 4 Influence of environmental variables on the occurrence and abundance of waterbirds at watery localities in summer. Notation used: Net ruf - Red-Crested Pochard, Ayt_ful -Tufted Duck, Ayt_fer - Pochard, Ana_str-Gadwall, Ful_atra - Coot, Egr_gar - Little Egret, Ans_ans - Greylag, Gal_ chlo - Moorhen, Tach_ruf - Little Grebe, Cyg_olo - Mute Swan, Egr_alb - Great White Egret, Hal_alb - White-tailed Eagle, Pha_carb - Cormorant, Buc_cla - Goldeneye, Ana_pla - Mallard, Nyc_nyc - Night Heron, Ste_hir - Common Tern, Pod_cris - Great Crested Grebe, Lar_rid - Black-headed Gull, Ard_cin - Grey Heron, Cor_cora - Raven, Cir_aer - Marsh Harrier, Acro_aru - Grear Reed Warbler, Acro_scir - Reed Warbler, Ixo_min - Little Bittern, Pan_hal - Osprey, Alc_att - Kingfisher, Rip_rip - Sand Martin. 
differed from the usual abundance of birds of the order Ciconiiformes during the nesting and migration season at NFS, was influenced by the autumn release and fish harvesting at the Naděje fishpond.

Sandpits showed the opposite trend. During the nesting period, waterbirds were not very abundant there. Mallard (Anas platyrhynchos) was the dominant species, followed by much smaller numbers of gadwall (Anas strepera) and mute swan (Cygnus olor). Great crested grebe (Podiceps cristatus) and grey heron (Ardea cinerea) occurred only in small numbers or sporadically in sandpits. No other species of this order were observed there. In winter, waterbirds in sandpits were quite numerous, but represented by only a few species. The dominant species was again mallard (Anas platyrhynchos), whose abundance reached more than two thousand individuals during this period.

Figure 4 shows CANOCO analysis of the total numbers of species of birds recorded in summer. The first axis explained $14.2 \%$ of the total variability, the first and second axis together explained $22.2 \%$ of the total variability, while for the indirect analysis (without the use of environmental variables) this percentage was $23.4 \%$.

Type of locality (fishpond/sandpit), diversity and number of species were used as the environmental variables and all of them were significant at the $5 \%$ significance level. This figure shows a higher preference for sandpits by sand martin (Riparia riparia), kingfisher (Alcedo atthis), osprey (Pandion haliaetus) and little bittern (Ixobrychus minutus). In contrast, fishponds are more attractive for red-crested pochard (Netta rufina), pochard (Aythya ferina), tufted duck (Aythya fuligula), greylag geese (Anser anser), coot (Fulica atra), moorhen (Gallinula chloropus), little grebe (Tachybaptus ruficollis), white-tailed eagle (Haliaetus albicilla) and little egret (Egretta garzetta). Species such as grey heron (Ardea cinerea), great white egret (Egretta alba), mute swan (Cygnus olor), black-headed gull (Larus ridibundus), common tern (Sterna hirundo), night heron (Nycticorax nycticorax), great crested grebe (Podiceps cristatus), mallard (Anas platyrhynchos), goldeneye (Bucephala clangula) and cormorant (Phalacrocorax carbo) did not show a significant preference for any type of locality.

Figure 4 also shows, which species were capable of reducing the abundance of other species of waterbirds in their vicinity by forming more numerous flocks. Species such as red-crested pochard (Netta rufina), pochard (Aythya ferina), tufted duck (Aythya fuligula) and gadwall (Anas strepera) formed less numerous flocks, which included other species.

\section{Discussion}

The total abundance of waterbirds at the fishponds monitored over the period 1986-2000 by (Ševčík 2005) was slightly different from that reported in this study.
However, the numbers of waterbirds that might be indicative of sudden changes in the factors influencing their occurrence did not change significantly at these fishponds. Data provided by the Administration of Třeboňsko PLA are relatively consistent with those presented here.

Older results (Balounová et al. 1996; Pešata 2003) indicate small numbers of waterbirds present at small fishponds (up to 5 hectares). The recent increase in the preference for smaller fishponds reported here may be influenced by food supply or the amount and localization of littoral vegetation, as the littoral vegetation provides shelter and building material for nests.

Another factor influencing the preference for fishponds may be the depth of the water, as birds are better able to access food in shallow water. A negative factor that can influence nesting success at these localities is human manipulation of the water level (and depth). The influence of this was not studied in detail, but the results obtained during 2005-2006 indicate that slight changes in water level can influence the different preferences of waterbirds for fishponds and sandpits during the nesting season.

Unlike fishponds, sandpits are more attractive in autumn and winter for those waterfowl that are migrating or overwintering. Larger areas of sandpits are suitable locations for aggregating prior to migration. Also, shooting is prohibited close to sandpits and therefore these reservoirs serve as refuges for birds during the hunting season. The most important factor, however, is the water in sandpits is free of ice during winter due to sand mining. The lower attractiveness of sandpits during the nesting season is due the fewer sources of food there and greater depth of water, which prevents some species of waterbirds from accessing food and the absence or only small areas of littoral vegetation resulting in fewer potential nesting sites for many species. The disturbing factor is the number of visitors, especially holidaymakers and fishermen.

\section{Conclusions}

Waterbirds prefer fishponds to sandpits during the nesting period because more food is available in fishponds for feeding to the young. Another factor is probably the occurrence there of more littoral vegetation. Sandpits are more attractive for waterbirds at other times of the year when they are mainly visited by some species during migration and for overwintering. Both of these habitats are important biotopes for waterbirds in the Protected Landscape Area (PLA), Biosphere Reserve and Important Bird Area (IBA) Třeboňsko.

\section{Acknowledgements}

Final processing of the results of this study was funded by project CZ.1.07/2.3.00/09.0076. 


\section{REFERENCES}

Balounová Z, Rajchard J, Vysloužil D, Macků E (1996) The study of ecological stability of Naděje fishpond system in relation to fish farming use. Report of the internal project ZF-2505/1996, University of South Bohemia, České Budějovice. (In Czech).

Barragan-Severo J, Lopez-Lopez E, Stanley KAB (2002) Spatial and temporal variation patterns of a waterfowl community in a reservoir system of the Central Plateau, Mexico. Hydrobiologia 3: 123-131.

Bezzel E (1976) On the evaluation of waterflowl biotopes. In Smart M (ed.), Proc. Int. Conf. Conserv. Wetlands and Waterfowl, Heiligenhafen, Germany. International Waterfowl Research Bureau, Slimbridge, pp. 294-299.

Hanák P, Tůma V, Vošta J (1985) Birds and mammals of sandpits, their parasite infestation, significance and use. Final report of the research project, University of Agriculture, České Budějovice. (In Czech).

Hudec K, Štastný K, Bejček V (2000) Long-term changes in the avifauna of CR. The development of nesting avifauna in the 20th century in CR. Sylvia 36: 2-5. (In Czech).

Janda J, Řepa P (1986) Methods of quantitative research in ornithology. Moravian Ornithological Society, Přerov. (In Czech)
Lutz M (2001) Fishponds in Eastern Europe. Typology of fish farming systems and effects of pond management on aquatic vegetation and nesting. Université Louis Pasteur, Strasbourg.

Matter WJ, Mannan RV (1998) Sand and gravel pits as fish and wildlife habitat in the Southwest. U.S. Fish and Wildlife Service, Resource Publication 171, Washington DC.

Musil P (2000) Fishponds and their management. Sylvia 36: 74-80. (In Czech).

Pešata M (2003) Occurrence of nesting waterbirds, depending on the type and condition of the littoral vegetation in Naděje fishpond system in PLA Třeboňsko, MSc. Thesis, University of South Bohemia, České Budějovice, Czech Republic. (In Czech).

Reitan O, Sandvik J (1996) An assesment of retaining dams in hydropower reservoirs for enhancing bird habitat. In: Brittain JE, Brinkman I, Nilsson C (eds), Proceedings of an International Workshop on Remedial Strategies in Regulated Rivers (25-28 September 1995, Lycksele, Sweden), pp. 23-24.

Siddle JG, Kirsch EM (1993) Least tern and piping plover nesting at sand pits in Nebraska, Colon. Waterbird 16: 139-148.

Statistica 8.0, StatSoft, Inc., STATISTICA (data analysis software system), version 8.0, 2007, www.statsoft.com.

Ševčík J (2005) unpublished internal database of management of PLA Třeboňsko. 